Winter 2013

\title{
Citizenship After the Conservative Movement
}

Elisabeth Zoller

Indiana University Maurer School of Law, ezoller@indiana.edu

Follow this and additional works at: https://www.repository.law.indiana.edu/ijgls

Part of the International Law Commons

\section{Recommended Citation}

Zoller, Elisabeth (2013) "Citizenship After the Conservative Movement," Indiana Journal of Global Legal Studies: Vol. 20 : Iss. 1 , Article 10.

Available at: https://www.repository.law.indiana.edu/ijgls/vol20/iss1/10

This Symposium is brought to you for free and open access by the Law School Journals at Digital Repository @ Maurer Law. It has been accepted for inclusion in Indiana Journal of Global Legal Studies by an authorized editor of Digital Repository @ Maurer Law. For more information, please contact rvaughan@indiana.edu.

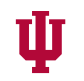

JEROME HALL LAW LIBRARY

INDIANA UNIVERSITY

Maurer School of Law
Bloomington 


\title{
Citizenship After the Conservative Movement
}

\author{
ELISABETH ZOLLER ${ }^{*}$
}

\begin{abstract}
Citizenship as a societal and political value has undergone major transformations under the conservative movement that took the lead in western democracies over the past forty years. In defining liberty as "absence of coercion" or "freedom from any restraint," the conservatives distorted the meaning of true liberty, which is "ordered liberty." In insisting on self-reliance as the prerequisite of individual insertion in society, they have precipitated an abatement in citizens' social and political rights that have had lingering effects on the social fabric, even today. Although these developments are domestic in nature, they greatly impact globalization insofar as they accelerate it by belittling the feeling of belonging to a nation in the citizens' hearts.
\end{abstract}

\section{INTRODUCTION}

Citizenship has undergone major transformations in the last century. Massive influxes of foreigners in Europe and North America have disrupted the traditional criteria that were used for granting it. The principles of jus soli (right of soil) and jus sanguinis (right of blood), which link citizenship to place of birth or filiation, survive, but they are no longer exclusive of other criteria. "Belonging" may result today from domicile or residency, that is, mere proximity. ${ }^{1}$ Consequently, instead of

* Professor of Public Law, Université Panthéon-Assas (Paris II), Visiting Professor of Law, Indiana University Maurer School of Law. Deep gratitude goes to Carol Greenhouse and Lauren Robel for stimulating an exchange of ideas. Warmest thanks are due to Rebecca Bertoloni-Meli and Peter Hook from the Indiana University Maurer School of Law Library for splendid scientific support and to Leora Baude for careful and meticulous editorial assistance. All errors are definitely mine.

1. From the variations in the criteria that must be satisfied in order to grant citizenship, two opposing tendencies in the definition of belonging have emerged: "On one hand, the expansionist view characterizes citizenship as a key concept in the survival and the reconstruction of the state. The restrictive view, on the other hand, identifies the decline in the relevance of citizenship as an opportunity for more appropriate and pluralistic social configurations to take hold." H. Patrick Glenn \& Dominic Desbiens,

Indiana Journal of Global Legal Studies Vol. 20, Issue 1 (2013)

(C) Indiana University Maurer School of Law 
being granted generously, citizenship nowadays has to be "earned" through various tests whose legitimacy is questioned. ${ }^{3} \mathrm{~A}$ second factor is an attitudinal-not factual-shift that is less visible than the demographic consequences of international migrations and has transformed citizenship even more deeply. That factor is the impact of forty years of conservative dominance in the United Kingdom and the United States, and later in Europe, particularly in Germany and France, save for a few liberal intervals. ${ }^{4}$

The conservative movement that has developed since World War II in the wake of the best seller by Friedrich Hayek, The Road to Serfdom, 5 took off with the inauguration of Richard Nixon to the presidency in 1969. Nixon came to power with an agenda tailored by the conservative ideology that grew out of the economic theory of neoliberalism, including companion disciplines such as public choice analysis and economic analysis of law. Libertarian on its margins, the conservative program can be summarized as follows: the less State there is the better. No one captured better the top conservative priority than Ronald Reagan, with the slogan that propelled him to power in a landslide victory, "Get the Government off our back!" The core idea of the conservatives was to disempower the State and empower the self; their ambition was to restore individual independence and individual self-reliance. Once in

LDappartenance au Québec: citoyenneté, domicile et résidence dans la masse législative québécoise, 48 MCGILL L.J. 117, 117 (2003) (Can.).

2. See Ayelet Shachar, Earned Citizenship: Property Lessons for Immigration Reform, 23 YALE J.L. \& HUMAN. 110, 135-36 (2011).

3. Some scholars find these tests deeply illiberal. This is the case when the tests ask for religious neutrality on the part of the candidate for naturalization and request her to forgo any ostentatious proselyte's garments such as the burka. The recently enacted Charter presented for the signature of every candidate for French citizenship, titled "Charter of Rights and Duties of the French Citizen," requests that he or she abide by laïcité. See Décret 2012-127 du 30 janvier 2012 approuvant la charte des droits et devoirs du citoyen français prévue à l'article 21-24 du code civil [Decree 2012-127 of January 30, 2012 Approving the Charter of Rights and Duties of French Citizens under Article 21-24 of the Civil Code], Journal OfFICIEL DE LA RePUblique FranÇaISE [J.O.] [OFFICIAL GAZETTE OF FRANCE], Jan. 31, 2012, p. 1769, available at http://www.legifrance.gouv.fr/ affichTexte.do?cidTexte=JORFTEXT000025241393. For a criticism of French immigration law, see Liav Orgad, Iliberal Liberalism: Cultural Restrictions on Migration and Access to Citizenship in Europe, 58 AM. J. CoMP. L. 53, 64-65 (2010).

4. These intervals include the era under Bill Clinton in the United States (19922000), Tony Blair in the United Kingdom (1997-2007), and Gerhardt Schröder in Germany (1998-2005). In France, the conservative movement took a strong hold in 1995 with the election of Jacques Chirac, and has been unbroken save for the socialist interval under Lionel Jospin (1997-2002), reaching its apex under the mandate of Nicolas Sarkozy (2007. 2012).

5. Friedrich Hayek, THE ROAD TO SERFDOM (1944). In a nutshell, the book demonstrated that socialism and planning led to serfdom. 
power, the conservative parties carried out this agenda with steadfast determination. They withdrew the rules (airline deregulation in the United States) or dismantled the institutions (breaking down the power of the workers' unions in the United Kingdom) associated with the welfare state. In the United States, the conservative agenda unfolded into three public policies. First, restoring individual independence and self-reliance meant a downsizing of the federal government together with a shifting of responsibilities to the states, which meant a new life for federalism and a resurrection of states' autonomy by a new distribution of powers between the federal government and the states. Second, restoring individual independence additionally meant a shifting of public responsibilities to the private sector, and thus, the privatization of large portions of governmental activities that used to be regarded as public services guaranteed by the State to its citizens. Third, restoring individual self-reliance eventually meant limiting the support that the federal government could bring, using its laws or its money, to those who were unable to be as self-reliant as the conservatives felt they should be.

Conservative programs had a profound impact on citizenship. The reason, pure and simple, is that citizenship does not equate with nationality. Citizenship is a foundational and structural institution of democracy, insofar as it is both a legal status and a societal and political value. As a status, citizenship bestows a collection of rights and a set of responsibilities on individuals who are free and equal in rights. As a value, citizenship determines the republican character of a society, since "as members of a common enterprise, all citizens [are] recognized as having civil, political, and social rights that ... ensure them full membership in the life of the society." 6 Both aspects are, of course, intertwined in reality, which explains why citizenship is meaningful in relation both to government and to society. In relation to government, citizenship is shaped by the liberal discourse that puts emphasis on individual rights; in relation to society, citizenship is, rather, framed by the republican discourse that insists on cohesiveness of society as a community -ideally, a society that is a community, a "Gemeinschaft," not only a "Gesellschaft." 8 Concretely, vis-à-vis government (or the (Can.).

6. Neil Brooks, Taxation and Citizenship, 48 LABour/LE TravaIL 353, 355 (2001)

7. On these two discourses, see Kathleen Knight Abowitz \& Jason Harnish, Contemporary Discourses of Citizenship, 76 REV. EDUC. RES. 653, 661-62 (2006).

8. For a classic work, the running theme of which is the opposition between "Gesellschaft" (affection or kinship based social relationship) and "Gemeinshaft" (social relationships based on duty to society), see generally FERDINAND TöNNIES, COMMUNITY AND SocietY [GemeinsChaft UND GeselischafT] (Charles P. Lommis ed. \& trans., Harper \& Row 1957) (1887). 
State), citizenship is the means to and the end of liberty: the means to liberty, insofar as it involves participation in government, particularly through the right to vote; and the end of liberty, because men enjoy liberty in society only if they live under laws. Vis-à-vis society, citizenship is the other side of equality; it is so closely linked to equality that the term "equal citizenship" is actually a tautological expression, because in a republic citizenship by definition means equality of rights. ${ }^{9}$ In a democracy, citizenship is not a privilege that may be granted by the sovereign at his discretion; it is a right.

The dual face of citizenship is important because if, legally speaking, citizenship is bestowed by the State, then socially speaking, it is created by society. It is therefore a "social fact," in Emile Durkheim's sense; an objective reality comprising representations and values capable of exercising external constraint on the individual. ${ }^{10}$ It determines the way people interact with the State and with each other; it shapes the feelings that people have for their countrymen, the emotions they share, and the way they view each other. Citizenship is a culture, and without that culture, the legal status of the citizen, with the accompanying rights and responsibilities, is meaningless. However, that culture of citizenship made of equal respect and mutual responsibilities barely survives today. Egotism rules society. Collective action is increasingly difficult to undertake, as exemplified by the rejection by large segments of the citizenry of the mandate imposed by the Patient Protection and Affordable Care Act on each citizen to buy individual health insurance. Citizens are not necessarily indifferent to their countrymen's fate, but they want to choose how much, when, how, and to whom they give. Charity tends to take the place of solidarity, and it demands to be customized to the individual preferences of the citizens; individualism has never been so strong, and the lonely crowd has never been so lonely. There is no easy answer to how this happened. But it is suggested hereinafter that, among the many factors that led to

9. Citizenship is so crucial in a republican society that this is arguably the reason why, in the landmark case Brown v. Board of Education, the Court pointed to compulsory education as "the very foundation of good citizenship" in rejecting as "inherently unequal" the "separate but equal" doctrine. 347 U.S. 483, 493, 495 (1954). In light of the decisive connection between society and citizenship underlined by the Court, Kenneth L. Karst is well founded in affirming, "[t]he principle of equal citizenship . . . means . . . [e]ach individual is presumptively entitled to be treated by the organized society as a respected, responsible, and participating member." KENNETH L. KARST, BELONGING TO AMERICA: EQUAL CITIZENSHIP AND THE CONSTITUTION 3 (1989).

10. ÉMILE DURKHEIM, LES RÈGLES DE LA MÉTHODE SOCIOLOGIQUE 25 (1894), available at http://classiques.uqac.ca/classiques/Durkheim_emile/regles_methode/regles_methode.html, translated in ÉMILE DURKhEIM, THE RuLEs OF SOCIOLOGICAL METHOD (George E. G. Catlin, ed., Sarah A. Solovay \& John H. Mueller, trans., Free Press 1965). 
this state of affairs, the conservative movement has played a decisive role in pervading the public views that have led to an unraveling of citizens' responsibilities and to a weakening of their rights.

\section{The UnRAVELing OF CitTIEns' ResPonsibilities}

Contemporary discourse on citizenship never starts with responsibilities, but rather with rights. This is intriguing insofar as the concept of citizenship, historically speaking, grew out of responsibilities. In the ancient republic of Rome, responsibilities were so predominant in citizenship that there was actually an office made of mandatory participation in the life of the city. This participation took three forms: military, fiscal, and political. The Roman citizen was a soldier, a taxpayer (or an assisted member if he could not support himself), and an elector. ${ }^{11}$ In the eighteenth century, the citizen was a member of a republic, often depicted as a "trustee" for the society to which he belonged, who held the right to vote and took an active role in the government of his polity. The understanding of citizenship as a trust and, consequently, as a power that could be misused, was central to the common law punishment for bribery regarding the improper discharge of the right to vote; the voter had a duty to use his vote honestly and in the public interest. ${ }^{12}$ Today, voters use their voting rights in their own personal, private interest so much so that politics are commonly regarded as being driven by individual preferences.

It is difficult to say when the change occurred. One thing is sure: in the founding era, citizenship was not understood as only a collection of individual rights. Thanks to the historiography of the second half of the twentieth century, "[i]t is no longer possible"-as Cass R. Sunstein insisted in his classical piece-"to treat the framers as modern pluralists believing that self-interest is the inevitable motivating force behind political behavior. Republican thought played a central role in the framing period." 13 The appeal of individualism took hold after the founding era. Suzanna Sherry suggests that the turning point occurred during the twentieth century: "Everyone now has rights, but no one has responsibilities. This form of radical individualism is a twentiethcentury innovation." 14 It might be closer to the truth to say that the last

11. Claude Nicolet, LE METIER De Citoyen DANS la ROME REPUblicaine 425 (2d ed. 1976).

12. Denis Baranger, The Eighteenth-Century Citizen, 7 EuR. REv. HIST. 251, 256-58 (2000).

13. Cass R. Sunstein, Beyond the Republican Revival, 97 YALE L.J. 1539, 1540 (1988).

14. Suzanna Sherry, Responsible Republicanism: Educating for Citizenship, 62 U. CHI. L. REV. 131, 148 (1995). 
century aggravated, rather than created, a trend that began well after the founding era. The nineteenth century saw the triumph of what may be called "naked liberty," that is, liberty in the absence of coercion. This is, today, the conservative definition of liberty, par excellence, but it is the opposite of the liberty organized by laws. "Ordered liberty" is the only form of liberty that the Court has protected since the New Deal. ${ }^{15}$

\section{A. From "Moral Liberty" to "Naked Liberty"}

Nothing is more important to understanding how citizens' responsibilities unraveled in the last third of the twentieth century than the conservative definition of liberty. For the past fifty years, the conservatives have been drumming into the public the view that liberty means absence of coercion, which is true in the philosophical or moral sense, but not in the legal sense. That definition was put in the neoliberal limelight by Friedrich Hayek in his book The Constitution of Liberty, which opens as follows: "We are concerned in this book with that condition of men in which coercion of some by others is reduced as much as possible in society. This state we shall describe throughout as a state of liberty or freedom." 16 Further, the author makes his point even clearer: "[W]e defined freedom as the absence of coercion." 17 Before Hayek, no one had defined liberty as concisely. Even the liberal John S. Mill, who influenced Hayek greatly with his negative version of liberty as "freedom from," did not set aside as much as Hayek did, the need in a society for "compulsion," "control," "coercion," or even "force" on the individual. ${ }^{18}$ Hayek was a libertarian ahead of his time. He marks a breaking point in the history of modern liberty that took shape in the revolutions at the end of the eighteenth century.

\section{Liberty at the End of the Eighteenth Century}

American and French revolutionaries who laid down the foundations of modern democratic systems did not define liberty as

15. See Section B infra.

16. F.A. HAYEK, THE CONSTITUTION OF LIBERTY 11 (1960).

17. Id. at 133.

18. John S. Mill wrote, for instance, in his essay On Liberty:

The object of this Essay is to assert one very simple principle, as entitled to govern absolutely the dealings of society with the individual in the way of compulsion and control, whether the means used be physical force in the form of legal penalties, or the moral coercion of public opinion.

John StuarT MiLL, ON LiBeRTy (P.F. Collier \& Son 1909) (1860) (emphasis added), available at $\mathrm{http} / / / \mathrm{www} . c o n s t i t u t i o n . o r g / j \mathrm{sm} / \mathrm{iberty} . \mathrm{htm}$. 
merely the absence of coercion. They did not disconnect liberty and control. They held liberty as an "unalienable right,"19 or a "natural and imprescriptible right," 20 that had to be "secure[d],"21 so "governments"22_" political association[s]"23-were "instituted among men" 24 for their "preservation." 25 These revolutionaries knew that liberty is a myth without a "government" or a "political association." 26 A government of some sort is needed for "the Blessings of Liberty"27 to be secured, with the result that, if governments are a necessity among men, liberty can certainly not be defined as "absence of coercion" since governments are, by nature and by definition, vested with the power to affect individual rights and liberties, and thus are necessarily coercive. ${ }^{28}$ Hence the question that needs to be asked is: If liberty was not "absence of coercion" at the end of the eighteenth century, what, then, was it?

At the end of the eighteenth century, liberty vis-à-vis government (or the State) was political liberty, that is, the possibility to live under a government of laws, not of men 29 -a government under whose authority people are citizens, not subjects. True liberty was the liberty actually enjoyed by man in relation to government and society; it was thus both political and civil liberty. But it could not be civil without being political, for liberty starts with the possibility to participate in the lawmaking process, thus, with citizenship. This explains why coercion by

19. THE DECLARATION OF INDEPENDENCE para. 2 (U.S. 1776).

20. DeClaration OF the RightS OF MAN AND OF THE Citizen (Fr. 1789), available at http://avalon.law.yale.edu/18th_century/rightsof.asp (last visited Mar. 13, 2013).

21. THE DECLARATION OF INDEPENDENCE, süpra note 19.

22. $I d$.

23. DEClaRATION OF THE RightS OF MAN AND OF THE Citizen, supra note 20.

24. THE DECLARATION OF INDEPENDENCE, supra note 19.

25. DECLARATION OF THE RightS OF MAN AND OF THE Citizen, supra note 20.

26. $I d$.

27. U.S. CONST. pmbl.

28. Even "[i]n protecting property the government is doing something quite apart from merely keeping the peace. It is exerting coercion wherever that is necessary to protect each owner, not merely from violence, but also from peaceful infringement of his sole right to enjoy the thing owned." Robert L. Hale, Coercion and Distribution in a Supposedly NonCoercive State, 38 PoL. SCI. Q. 470, 472 (1923).

29. The phrase "government of laws, not of men" gained currency when John Adams used it in Article Thirty of the Bill of Rights of the Massachusetts Constitution of 1780. BARTELBY.COM, http://www.bartleby.com/73/991.html (last visited Sept. 7, 2012). In 1774, Adams published articles in the Boston Gazette using the pseudonym "Novanglus." Id. There, he credited James Harrington with having made prior use of that formulation. Novanglus No. 7 (John Adams) (1774), reprinted in 4 THE WoRKS OF JOHN ADAMS 106 (Charles Francis Adams ed., Boston, Charles C. Little \& James Brown 1851). Harrington had, in fact, described government as "the empire of laws and not of men" in his 1656 work, The Commonwealth of Oceana. BARTELBY.COM, http://www.bartleby.com/73/991 (last visited Mar. 13, 2013). 
democratically-enacted laws was definitely not regarded as negation of liberty. For the men of the eighteenth century, liberty had a dual meaning, a philosophical and moral sense on the one hand, and a legal sense on the other. From a philosophical and moral perspective, liberty was defined as absolute freedom from restraints-total independence of the body or the mind. From a legal standpoint, liberty was defined more narrowly. Montesquieu set the tone of legal liberty when he defined liberty as follows: "[L]iberty consists only in the power of doing what we ought to will, and in not being constrained to do what we ought not to will." 30 His subtle formula forms the background of the definition of liberty adopted in Article 4 of the Declaration of the Rights of Man and of the Citizen: "Liberty consists in the freedom to do everything which injures no one else; hence the exercise of the natural rights of each man has no limits except those which assure to the other members of the society the enjoyment of the same rights." 31 In the United States, as Charles Warren recalled in a classic piece on the evolutionary meaning of "liberty" under the Fourteenth Amendment, "liberty' meant simply 'liberty of the person,' or, in other words, 'the right to have one's person free from physical restraints." 32 Gradually, however, after the adoption of the Fourteenth Amendment, liberty no longer meant "freedom from physical restraint of the person" alone; it started to mean "freedom from any restraint," tout court. A key factor in the evolution was the influence of utilitarianism, the philosophy that the purpose of all action should be to bring about the greatest happiness for the greatest number.

\section{The Transformation of Liberty in the Nineteenth Century}

Happiness as the aim of all action existed in the classical age of liberty, as exemplified by the famous "pursuit of happiness" presented as a legitimate end of individual action under a government of laws in the Declaration of Independence. But it was not the happiness that people are longing for today. It was the public happiness of the greatest

30. 1 M.de Secondat, Baron De Montesquied, The SPIRIT of LaWs bk. XI ch.3, at 161 (J.V. Prichard ed., Thomas Nugent trans., G. Bell \& Sons 1914) (1748), available at http://heinonline.org.ezproxy.lib.indiana.edu/HOL/Page?handle=hein.beal/sol0001\&id=210 \&collection=beal\&index.

31. Declaration OF THE Rights of MAN AND OF THE Citizen, supra note 20, at art. IV, translated in ARTHUR TAYLOR VON MEHREN \& JAMES RUSSELL GORDLEY, THE CIVIL LAW SySTEM: AN INTRODUCTION TO THE COMPARATIVE STUDY OF LAW 229 n.37 (2d ed. 1977).

32. Charles Warren, The New "Liberty" Under the Fourteenth Amendment, 39 HaRV. L. REV. 431, 440 (1926). 
number. ${ }^{33}$ Common wisdom held that the pursuit of private happiness by the individual necessarily works for the benefit of all his countrymen. ${ }^{34}$ In case it did not, government would redress the course of action and adjust private happiness to the public good. Reconciliation between private happiness and public good eventually rested with the private morality of each citizen. James Madison said before the Virginia Ratifying Convention, "I go on this great republican principle, that the people will have virtue and intelligence to select men of virtue and wisdom." 35 The difficulty is that citizens' virtue and intelligence turned into relics of the past once the founders' generation was gone and a capitalistic economy replaced the simple market economy of the founding era.

Many political, social, and economic factors explain the transformation. But a fatal breaking point was thrust forward in the early nineteenth century by Jeremy Bentham, the father of utilitarianism, who precipitated the decline of moral liberty and the triumph of naked liberty when he endeavored to discredit Montesquieu on the ground that

[o]f happiness, he says nothing: instead of security for the people against their rulers, he talks of liberty: and assumes without directly saying so, that to establish the most perfect liberty is the proper object of all government: whereas government cannot operate but at

33. For instance, in a paper published in 1774, Thomas Jefferson wrote: "[O]ur ancestors, before their emigration to America, were the free inhabitants of the British dominions in Europe, and possessed a right, which nature has given to all men, [of] . . establishing new societies, under such laws and regulations as to them shall seem most likely to promote public happiness." Thomas Jefferson, A Summary View of the Rights of British America, in 1 THE FoUnders' CONSTTTUTION 435, 435 (Philip B. Kurland \& Ralph Lerner eds., 1987) (emphasis added), available at http://press-pubs.uchicago.edu/founders/documents/v1ch14s10.html.

34. In 1787, John Stevens, Jr., commenting upon the freshly adopted Constitution, rejoiced himself and his readers as follows:

A Government formed on this plan, requires in the execution of it, none of those heroic virtues which we admire in the antients [sic], and to us are known only by story. The sacrifice of our dearest interests, self-denial, and austerity of manners, are by no means necessary. Such a Government requires nothing more of its subjects than that they should study and pursue merely their own true interest and happiness.

AMERICANUS No. 3 (John Stevens, Jr.) (1787), reprinted in THE DEBATE ON THE CONSTITUTION, pt. 1, at 437, 441 (1993).

35. James Madison, Virginia Ratifying Convention Speech (June 20, 1788), in 1 THE FOUNDERS' CONSTITUTION, supra note 33 , at 409 , available at http://presspubs.uchicago.edu/founders/documents/v1ch13s36.html. 
the expense of liberty, and then and there only is liberty perfect, where no government has place. ${ }^{36}$

Bentham's reading of Montesquieu was very unfortunate. In defending the right to happiness at all costs, and in doing away with governments considered as necessarily operating at the expense of liberty, Bentham turned the idea of liberty into "unlimited freedom," or mere "independence." The difference between the two concepts is, however, fundamental, because as Montesquieu said,

[w]e must have continually present to our minds the difference between independence and liberty. Liberty is a right of doing whatever the laws permit, and if a citizen could do what they forbid he would be no longer possessed of liberty, because all his fellow-citizens would have the same power. ${ }^{37}$

In short, and to oversimplify, when independence replaces liberty, when the market drives the State away, the society is no longer under the rule of law, but rather under the law of the jungle.

Utilitarianism found a very receptive audience in the Anglo-American world, if not on the continent. In Europe, the legacy of Roman law, a strong feeling for the State as the embodiment of the res publica ${ }^{38}$ (the public good as the basis of the social contract) together with an influential German philosophy driven by rationalism and morality (as exemplified by Immanuel Kant) rolled back the market as the driving force of society and forestalled a creed for total liberty as the absence of coercion. In the United States, on the contrary, utilitarianism gained wide currency in legal circles. It became the philosophical foundation of litigation. Lawyers played a critical role in championing a particular Hayekian vision of liberty through the pre-New Deal period. In order to bring satisfaction to their ever-demanding clients, skillful counsel attempted to include all a person's civil rights in the word "liberty." 39

36. 9 JEREMY BENTHAM, Constitutional Code, in THE WORKS OF JEREMY BENTHAM 123 (John Bowring ed., Edinburgh, William Tait 1843).

37. MONTESQUTEU, supra note 30, at 161 .

38. See EliSABETH ZOLLER, INTRODUCTION TO PUBLIC LAW: A COMPARATIVE STUdY 22, 258-59, 270-72 (2008). See generally Elisabeth Zoller, Public Law as the Law of Res Publica, 32 SufFolK TRANSNAT'L L. ReV. 93 (2008).

39. See Warren, supra note 32 , at $435-40$ (explaining that the Bar was a highly active force in the transformation of the concept of liberty in the nineteenth century). 
In 1838, Francis Lieber, a German-American philosopher, published a Manual of Political Ethics, largely influenced by utilitarianism, that was adopted by Harvard College as a textbook and was highly commended by James Kent and Joseph Story. In 1849, Lieber published a paper titled Anglican and Gallican Liberty in a South Carolina newspaper, in which he lined up the following assertions:

[W]e have in the province of political freedom an Anglican and Gallican school. . . Independence in the highest degree, compatible with safety and broad national guarantees of liberty, is the great aim of Anglican liberty, and self-reliance is the chief source from which it draws its strength.

. . Public interference is odious to [the English and Americans]. Government with them, is not considered the educator, leader, or organizer of society. On the contrary, in reading the many constitutions which this race has produced ... . we almost fancy to read over all of them the motto, "Hands off."

Quite different from Anglican is Gallican liberty. $\ldots$

Gallican liberty . . . is sought in the government, and, according to an Anglican point of view, it is looked for in a wrong place, where it cannot be found. Necessary consequences of the Gallican view are, that the French look for the highest degree of political civilization in organization, that is, in the highest degree of interference by public power. ${ }^{40}$

In pointing to "organization" instead of "law," Lieber distorted the meaning of the Declaration of 1789 . This Declaration clearly says that

40. 2 Francis Lieber, Anglican and Gallican Liberty, in The Miscellaneous WRITINGS OF FRANCIS LieBER 369, 377-383 (Philadelphia, J.P. Lippincott Co. 1881). 
"limits [to liberty] can only be determined by law," 41 that is to say, constitutional and statutory law, since "law" in the French text always means "the expression of the general will," that is, law adopted by the people themselves or their representatives. His deceitful exposition of Gallican liberty should, however, come as no surprise, for regulation of liberty by laws is precisely what Lieber cursed as legal anathema. Taking rights as seriously as Ronald Dworkin in the twentieth century, he is convinced, like Lieber, that "[i]f someone has a right to something, then it is wrong for the government to deny it to him even though it would be in the general interest to do so." 42 Lieber's negative views on statutory law, which he equated with "organization," set the stage for an enduring distaste among U.S. lawyers for the civil law system adopted on the European Continent.43 As for Hayek, he set great store by Lieber's opposition between Anglican and Gallican liberty and affirmed without batting an eyelid: "[W]e have had to the present day two different traditions in the theory of liberty: one empirical and unsystematic, the other speculative and rationalistic." 44 Doubt may be cast as to whether by "the present day," that is, in 1960 when The Constitution of Liberty was published, the United States, and the United Kingdom for that matter, still adhered to an "empirical and unsystematic" approach to liberty. It would have been closer to the truth to say that both countries did so adhere during the Gilded Age when liberty-as the absence of coercion-carried the day of the policy of laissez-faire, when the free market was the rule, and when regulation was the exception. "Naked liberty" ruled; it was a purely idealistic approach to liberty, based on ethical and economic theories rejected by the Supreme Court under the New Deal, when the Court changed its definition of liberty to meet the challenge issued to the nation by "one-third of a nation ill-housed, ill-clad, ill-nourished." 45

41. DeClaration of the Rights of MAN AND OF THE Citizen, supra note 20.

42. RONALD DWORKIN, TAKING RIGHTS SERIOUSLY 269 (1977).

43. Lieber's Kulturkampf against the civil law system forms the background of the divide that he sets between, on the one hand, England and America, and on the other, France in particular and the European continent in general. The thrust of his Manichean analysis is well-illustrated by this recommendation: "The principles of our liberty, therefore, are peculiarly necessary to the people of the European continent. Many of them seem to fall into the same unfortunate delusion of expecting everything from organization by public power." 2 LIEBER, supra note 40 , at 388 .

44. HAYEK, supra note 16 , at 54 (footnotes omitted).

45. Franklin D. Roosevelt, The Second Inaugural Address (Jan. 20, 1937), in 1937 PUBlic PAPERS AND ADDRESSES OF FRANKLIN D. RoOSEVELt 1, 5 (Samuel I. Rosenman ed., 1941). 


\section{B. From "Naked Liberty" to "Ordered Liberty"}

The intrinsic contradiction of libertarianism is in its fragile ethical foundations. Libertarians know that market rationality is not enough to supply the civic virtues that are indispensable in a republic. But, like the Victorians of the late nineteenth century, they rely on the "inner check' of classical humanism" to rein in misuses and abuses of rights and liberties. ${ }^{46}$ As Lieber credulously believed: "The greater the liberty, the more the duty. For, the less bound or circumscribed we are in our actions from without, the more indispensable it becomes that we bind ourselves from within, that is, by reason and conscience." 47 That is why conservatives set great store by religion, for this is where they find their morality. True morality for them is always private, never public; it is individual, never social. ${ }^{48}$ In their view, morality is internalized; it resides in the inner self only. Such confidence in individual self-control-the automatic pilot, so to speak, of their economic theoryis appealing, even enticing, but at the same time very naive. It convinced neither the American nor the French revolutionaries who knew from experience that " $[\mathrm{w}]$ herever there is an interest and a power to do wrong, wrong will generally be done," 49 and that this is especially the case "between the strong and the weak, between the rich and the poor, between the master and the servant,"50 with the result that, in grossly unequal relations, "it is freedom which oppresses and the law which sets free." 51

\section{The Demise of Libertarianism}

Libertarianism foundered during the Great Depression, when the Court acknowledged that there must be limits to liberty, reversing course with respect to even the most entrenched ideas. At the beginning of the last century, nowhere was liberty, defined as the absence of

46. John Patrick Diggins, From Pragmatism to Natural Law: Walter Lippmann's Quest for the Foundations of Legitimacy, 19 POL. THEORY 519, 520 (1991).

47. 2 Francis Lieber, Manual of Political Ethics 2 (Boston, Charles C. Little \& James Brown 1839).

48. See David Marquand, Decline of the Public 92 (2004).

49. Letter from James Madison to Thomas Jefferson (Oct. 17, 1788), in 1 THE FOUNDERS' CONSTITUTION, supra note 33 , at 477,477 , available at http://presspubs.uchicago.edw/founders/documents/vlch14s47.

50. R.P. HENRI-DOMINIQUE LACORDAIRE, CONFERENCES DE NOTRE-DAME DE PARIS, Tome III, 494 (1846) (" [E]ntre le fort et le faible, entre le riche et le pauvre, entre le maître et le serviteur, c'est la liberté qui opprime et la loi qui affranchit") http:/gallica.bnf.fr/ark:/12148/bpt6k202681x.

51. Id. 
coercion, more cherished than in the right to contract about one's affairs, particularly in employment matters, when that right was exercised for contracts of labor. In that domain, some members of the Court had turned liberty of contract into a dogma. For instance, in 1905, Justice Peckham was convinced that "unreasonable, unnecessary, and arbitrary interference with the right of the individual to his personal liberty" 52 was inadmissible as a rule, on the ground that "[t]here must be more than the mere fact of the possible existence of some small amount of unhealthiness to warrant legislative interference with liberty."53 Likewise, in 1923, Justice Sutherland was persuaded that "[t]o sustain the individual freedom of action ... is not to strike down the common good, but to exalt it; for surely the good of society as a whole cannot be better served than by the preservation against arbitrary restraint of the liberties of its constituent members." 54 Put simply, it did not take long before these idealist judges discovered they were wrong. Leaving aside the constitutional reasons why they were in error, it is no small feat that in 1978, Ronald Coase himself reminded hasty borrowers of economic theories for the advancement of other social sciences, such as law, that "it by no means follows that an approach developed to explain behavior in the economic system will be equally successful in the other social sciences." 55

In 1937, the Court abandoned the dogmatic approach to liberty that prevailed during the Gilded Age. It eventually agreed with Justice Holmes, who, as early as 1923, noticed that "[c]ontract is not specially mentioned in the text that we have to construe."56 Reversing course in the landmark case West Coast Hotel Co. v. Parrish, the Court affirmed:

The Constitution does not speak of freedom of contract. It speaks of liberty and prohibits the deprivation of liberty without due process of law. In prohibiting that deprivation, the Constitution does not recognize an absolute and uncontrollable liberty. Liberty in each of its phases has its history and connotation. But the liberty safeguarded is liberty in a social organization which requires the protection of law against the evils which

52. Lochner v. New York, 198 U.S. 45, 56 (1905).

53. Id. at 59 .

54. Adkins v. Children's Hosp. of D.C., 261 U.S. 525, 561 (1923).

55. Ronald H. Coase, Economics and Contiguous Disciplines, 7 J. LEGAL STUD. 201, 208 (1978).

56. Adkins, 261 U.S. at 568 (Holmes, J., dissenting). 
menace the health, safety, morals, and welfare of the people. ${ }^{57}$

Parrish set the stage for the building of the welfare state, the "administrative state" that has been the nightmare of conservatives for the past fifty years. It strategically altered the definition of liberty to effectuate a return to the pre-New Deal era. In line with Hayek, the conservatives proposed to define liberty as "that condition of men in which coercion of some by others is reduced as much as is possible in society." 58 True, Hayek admitted that there were degrees in coercion and that some degrees were more tolerable than others. He was too intelligent to suggest doing away with coercion entirely. But, by identifying liberty with the absence of coercion, he set the tone of the discourse that conservatives have held about liberty for so long: any governmental interference with the freedom of the individual is always coercive by definition and thus presumed, from the outset, to be illegitimate. The weakest point of the conservative theory is its starting point, the definition of liberty as the absence of coercion, which is at odds with what the Court said in Parrish.

In recalling that "the liberty safeguarded is liberty in a social organization," the Court shone a bright light on the reality that law, which forms the backbone of social organization, is always needed in case of any exercise of any liberty. ${ }^{59}$ If law is always needed, liberty cannot be defined as the absence of coercion, for law is a vivid expression of the coercive power of the state through enforcement. The state is an inherently coercive instrument when it acts through officers (e.g., police officers, tax officials, and judges) vested by law with the power to make determinations or to take action with the purpose and effect to alter the legal rights, duties, and relations of persons, against their own will, and thus, against their liberty. After decades of blind adherence to idealized liberty free from any restraint, the Court rallied around the position propounded by Montesquieu in The Spirit of Laws, and developed by the French revolutionaries in the 1789 Declaration of Rights of Man and the Citizen, to wit, that the liberty protected in a social organization is never "naked," it is always organized by the lawmakers, that is, limited when necessary, guaranteed by enforcement mechanisms, and protected by the courts. In short, liberty in modern democracies is always "ordered liberty," as Justice Cardozo felicitously called it. ${ }^{60}$ No better definition of liberty in a social organization has

57. West Coast Hotel Co. v. Parrish, 300 U.S. 379, 391 (1937).

58. HAYEK, supra note 16 , at 11.

59. Parrish, 300 U.S. at 391.

60. Palko v. Connecticut, 302 U.S. 319, 325 (1937). 
ever been found. The concept of "ordered liberty" in its conciseness refutes the idea that liberty can be merely "absence of coercion" and, at the same time, underlines the reason why citizenship is crucial, for only citizenship gives to the individual the right to take part in "ordering" it.

\section{The "New" Liberty}

Since the New Deal, liberty may no longer be defined as mere absence of coercion. Even before that watershed in U.S. constitutional history, this was already the case. Actually, nobody has ever pushed the argument that liberty was the absence of coercion, pure and simple, to the extreme, except the anarchists who reject government. Everyone recognizes that some degree of coercion is necessary in a social organization; this is the price that has to be paid to secure liberty and to enact the transformation of "natural liberty" into "ordered liberty." In The Federalist, John Jay insisted that "[n]othing is more certain than the indispensable necessity of government."61 Alexander Hamilton went even further: "A nation, without a national government, is, in my view, an awful spectacle."62 Far from being antagonistic, liberty and government are linked to each other; the former disappears when the latter withers away. Even when it was invisible by contemporary standards, as was the case in the Gilded Age, the State was very present in citizens' daily life. Justice Holmes noticed in his dissent in Lochner v. New York:

[S] tate constitutions and state laws may regulate life in many ways ... . The liberty of the citizen to do as he likes so long as he does not interfere with the liberty of others to do the same, which has been a shibboleth for some well-known writers, is interfered with by school laws, by the Postoffice [sic], by every state or municipal institution which takes his money for purposes thought desirable, whether he likes it or not. 63

Hayek himself recognized that "[c]oercion . . . cannot be altogether avoided because the only way to prevent it is by the threat of coercion. Free society has met this problem by conferring the monopoly of coercion on the state." 64 But he insisted that the coercion which a

61. The Federalist No. 2, at 37 (John Jay) (Clinton Rossiter ed., 1961).

62. The FEDERALiST No. 85, at 527 (Alexander Hamilton) (Clinton Rossiter ed., 1961).

63. 198 U.S. at 75 (Holmes, J., dissenting).

64. HAYEK, supra note 16 , at 21 (footnotes omitted). 
government uses for this end must be "reduced to a minimum and made as innocuous as possible by restraining it through known general rules, so that in most instances the individual need never be coerced unless he has placed himself in a position where he knows he will be coerced."65

The difficulty is that these "general rules" have multiplied since Hayek wrote his book. Nowadays, the State is omnipresent in citizens' lives. It protects them against external and internal enemies; it even protects them against themselves. Here is the real problem, for, as Isaiah Berlin said, "[w]e must preserve a minimum area of personal freedom if we are not to 'degrade or deny our nature."'66 How wide is that area today? In the early twenty-first century, the Court was called on to make a determination on the issue. The answer the Court gave provides much food for thought. Per Justice Kennedy, the Court said:

Liberty protects the person from unwarranted government intrusions into a dwelling or other private places. In our tradition the State is not omnipresent in the home. And there are other spheres of our lives and existence, outside the home, where the State should not be a dominant presence. Freedom extends beyond spatial bounds. Liberty presumes an autonomy of self that includes freedom of thought, belief, expression, and certain intimate conduct. 67

If words make sense, absolute liberty-liberty as the absence of any coercion, compulsion, or control-is the "autonomy of self." That definition certainly encompasses liberty of religion, opinion, expression, and sexual orientation (coercion in these various matters is never legitimate); however, it is doubtful that it includes property, even property at home.

The liberty to enjoy, to use, and to alienate property is, like all other liberty, "ordered liberty." It may be more or less ordered, but there is hardly any liberty, save the liberty of the mind, that cannot be regulated by the state as it wants, how it wants, and when it wants, without having to leave any choice to those affected by the legislative program. ${ }^{68}$ Under such conditions, to keep clinging to the idea that

65. Id

66. ISAIAH BeRLIN, Two CONCEPTS OF LIBERTY (1958), reprinted in THE PROPER STUdY OF MANKIND 191, 198 (Henry Hardy \& Roger Hausheer eds., 1997).

67. Lawrence v. Texas, 539 U.S. 558, 562 (2003).

68. As insinuated by the Court of Appeals for the Eleventh Circuit in the famous case Florida ex rel. Attorney General v. United States Department of Health \& Human Services, "[t]he Act's economic mandate to purchase [health] insurance . . . leaves no choice. . . . 
liberty means the absence of coercion is a pipe dream; it is out of touch with the necessities of the time. For, if coercion may always be imposed on individuals, then true liberty is to give them the right to have a say in the forms and the degree of coercion that may bear upon them. In short, liberty is political liberty, or, as Justice Breyer put it in an engaging and dense short essay, new liberty is "active liberty." 69

Working out an opposition made by the French political theorist, Benjamin Constant, between the collective liberty of the ancients, aimed at ensuring the welfare of the City, and the individual liberty of the moderns, oriented more toward the peaceful enjoyment of private happiness, ${ }^{70}$ Breyer argues that "we must "learn to combine the two together."'71 In Breyer's opinion, the necessary combination of both liberties is commanded by "the Constitution's democratic nature."72 Constant, too, argued for the need to combine both liberties because, as he saw it, it was the only way to overcome naked utilitarianism:

[I]s it so true that happiness of whatever sort is mankind's only aim? If it were, we would be moving along a narrow path to a rather low destination .... What our destiny calls us to is not happiness alone but to the improvement of ourselves; and political liberty is the most powerful, the most active means of improvement that heaven has given us. ${ }^{73}$

As Breyer underlined, in insisting on the Constitution's democratic nature, the Founding Fathers were well aware that democratic participation of the citizenry was the most important means by which the citizen may rise to the level of moral liberty. That is why, as several

Individuals subjected to this economic mandate have not made a voluntary choice to enter the stream of commerce, but instead are having that choice imposed upon them by the federal government." 648 F.3d 1235, 1291-92 (11th Cir. 2011), aff'd in part, rev'd in part sub nom. Nat'l Fed'n of Indep. Bus. v. Sebelius, 132 S. Ct. 2566 (2012).

69. See StEPHEN BREYER, ACtive LibERTY: InTERPRETING OUR DemocratiC CONSTITUTION 5 (2005).

70. Benjamin Constant, De la liberté des anciens comparée à celle des modernes [The Liberty of the Ancients Compared with that of the Moderns] (1819), available at http://www.panarchy.org/constant/liberte.1819.html [hereinafter Constant], translated in EARLY MODERN TEXTS, http://www.earlymoderntexts.com/pdf/conslibe.pdf. (Apr. 2010) (Jonathan Bennett, trans.) [hereinafter Bennett].

71. BREYER, supra note 69, at 5 (quoting an excerpt from Constant, supra 70). There can be no doubt that Constant himself did recommend a combination of the two types of liberty; see, however, the reservations by Cass R. Sunstein, Justice Breyer's Democratic Pragmatism, 115 YALE L.J. 1719, 1722 (2006).

72. BREYER, supra note 69 , at 5-6.

73. Bennett, supra note 70 , at 13 . 
American scholars have argued as early as the late $1980 \mathrm{~s}$, when neoliberalism was at a peak, ${ }^{74}$ the U.S. Constitution is not made of liberal, Lockean fabric only, but has a definitely republican component too. Citizenship implies duties, not rights only. The conservative movement did not object to that principle, quite the contrary, but it failed to provide for the means to effectively enforce it because of its top priority, to downsize government and public service, the most important means by which citizen's rights are guaranteed.

\section{The ABatement of Citizen's Rights}

The conservative movement came to power with the agenda of restoring individual self-reliance and doing away with big government on the grounds that it stifled private initiative. On its face, such an agenda looked like a formidable boost to individual liberty, and it was in a sense, provided that one understands the nature of the liberty at stake: that liberty is a right of man, not a citizen's right. For a basic tenet in the conservative discourse on rights is that the rights they care for are the rights of man, not those of the citizen. The distinction is of great import, because if one can be a man (or a woman) alone, one is never a citizen alone. Etymologically, citizenship implies a "city"; it implies a community, a society, a state. The problem is that conservatives believe in the individual, not in society.

Nobody expressed that philosophy better than Margaret Thatcher when she said, in a now legendary interview:

I think we have gone through a period when too many children and people have been given to understand "I have a problem, it is the Government's job to cope with it!" or "I have a problem, I will go and get a grant to cope with it!" "I am homeless, the Government must house me!" and so they are casting their problems on society and who is society? There is no such thing! There are individual men and women and there are families and no government can do anything except through people and people look to themselves first. ${ }^{75}$

74. See generally Sherry, supra note 14; Sunstein, supra note 13.

75. Interview by Douglas Keay with Margaret Thatcher, Prime Minister of the United Kingdom, in London, England (Sept. 23, 1987), available at http:/www.margaretthatcher.org/ document/106689. 
The difficulty is that, in modern democracies, society coincides with government, because the source of all power, including governmental power, is in the people. Therefore, it is misleading to affirm that "no government can do anything except through the people." Quite the contrary, a republican government can do a lot by itself, through its own resources, its own organs, and its own institutions, because it is, as Abraham Lincoln famously stated in the Gettysburg Address, a "government of the people, by the people, for the people."76

Lincoln's definition of democracy took a long time to materialize. It eventually came into being under the New Deal, when Americans discovered the second meaning of citizenship. If the Civil War taught the prerequisite of that republican concept-complete equality of rights between human beings-the Great Depression confronted the American people with the true meaning of citizenship-dependence on each other. Franklin D. Roosevelt gave an excellent definition of citizenship when he said in his First Inaugural Address, "[W]e now realize as we have never realized before our interdependence on each other; that we cannot merely take but we must give as well." 77 To give flesh to interdependence between citizens-to make it real-complex governmental institutions and numerous administrative agencies dedicated to public service were created. The conservative movement has relentlessly argued that these institutions are useless because, through their rules and procedures, they are a constant reminder to individuals hasty to pursue happiness through their own means that they are not alone and that they live in an organized society.

Conservative programs everywhere aimed at downsizing government and enhancing individual self-reliance. These policies were pursued most actively in the United Kingdom and the United States, but also in continental Europe. Everywhere they led to a relaxation of social cohesiveness; the social fabric unraveled in proportion to the conservative governance; conservatives forced democracies to effectuate a return to the pre-New Deal era, when the rights of man, not citizens' rights, ruled the day. The change was huge as evidenced by its consequences. Those most affected by these choices were the weakest members of society-the elderly, the youth, women, and minorities. True, these people can still claim that they are citizens, but only through their voting rights. Conservatives have brought social rights

76. Abraham Lincoln, Gettysburg Address (Nov. 19, 1863), available at http://showcase.netins.net/web/creative/lincoln/speeches/gettysburg.htm.

77. Franklin D. Roosevelt, Inaugural Address (Mar. 4, 1933), in 2 PUBLIC PAPERS AND ADDRESSES OF FRANKLiN D. RoOSEvelT 11, 14 (Samuel I. Rosenman ed., 1938). 
close to the vanishing point, and they even depreciated political rights by applying the insights of economic analysis to the political process. ${ }^{78}$

\section{A. The Vanishing Point of Social Rights}

A top priority on the conservative agenda-restoration of self-reliance-meant in the first place putting an end to the support that the State may provide by its laws or its money to those who are unable to be as self-reliant as they should be, according to conservative morality. Social rights that had developed in the wake of the Great Depression and World War II had to be reduced or withdrawn. These decisions had a formidable impact on social cohesiveness, because the social rights that Franklin D. Roosevelt presented as a "second Bill of Rights" on January 11, 1944, carried with them a profound message for society as a whole and for the world as well: "We cannot be content, no matter how high that general standard of living may be, if some fraction of our people-whether it be one-third or one-fifth or one-tenth-is illfed, ill-clothed, ill-housed, and insecure."79

Social rights stood for an aspiration to narrow the gap between the working class and the wealthy by associating basic human equality ("all men are created equal") ${ }^{80}$ to the concept of full membership in the community, that is, to citizenship. As T.H. Marshall explained in his magisterial essay, Citizenship and Social Class, citizenship in the twentieth century was turned into a template for "modifying the whole pattern of social inequality." 81 Many people took alarm at such consequences, especially the wealthy. Huge financial means were mobilized to convince the public that the "unconditional war on poverty" launched by Lyndon Johnson in 1964 paved the road to socialism. ${ }^{82}$ Today, social rights still exist, but they are offered more parsimoniously than before, mostly to those who, through age or sickness, are no longer capable of keeping up with the race. More importantly, they no longer carry the same message for society. Conservatives divorced social rights from the status of citizenship and made social rights operate rather as a safety net for the elderly rather than as a social ladder for the young.

78. See Section B, infra.

79. Franklin D. Roosevelt, Message to the Congress on the State of the Union (Jan. 11, 1944), in 1944-45 PUBlic PAPERS AND AdDREsses of FrankLIN D. Roosevelt 32, 40 (Samuel I. Rosenman ed., 1950).

80. THE DEClaRATION OF INDEPENDENCE, supra note 19.

81. T.H. MARShall, Citizenship and Social Class, in CitTzEnShIP AND Social Class AND OTHER ESSAYS 1, 47 (1950).

82. See Dan T. Carter, The Rise of Conservatism Since World War II, 17 MAG. OF HIST. 11,13 (2003). 
This is especially the case with access to college, which in most western democracies is less and less supported by public policies and more and more shifted to private choice and the private responsibility of students.

\section{1. "No Fundamental Interest in Food, Shelter, [or] Education"s3}

As early as 1970, the Supreme Court began to limit federal protection for the poor. Distancing itself from the Warren Court's assertive defense of social equality through a strict scrutiny analysis of any infringement of "fundamental interest," it decided to abide by a rational basis approach in the areas of economics and social welfare. In Dandridge $v$. Williams, the Court upheld a state welfare cap of $\$ 250$ per month per family regardless of the size of the family and its actual need, stating: "[A] State does not violate the Equal Protection Clause merely because the classifications made by its laws are imperfect." ${ }^{4}$ Two years later, it rejected the argument that, in housing matters and shelter for the needy, a more stringent standard than mere rationality was called for. Stating, without denigrating "the importance of decent, safe, and sanitary housing," the Court took its own shelter in the silence of the Constitution: "[T]he Constitution does not provide judicial remedies for every social and economic ill ... . Absent constitutional mandate, the assurance of adequate housing . . . [is] [a] legislative, not judicial, function $[., 85$

More important for the meaning of citizenship, the same rationality test was applied to adjudicate equal protection cases in education. This jurisprudential policy was a crucial setback for citizens' rights for, as T.H. Marshall had noticed

[t] he right to education is a genuine social right of citizenship, because the aim of education during childhood is to shape the future adult. Fundamentally it should be regarded, not as the right of the child to go to school, but as the right of the adult citizen to have been educated. ${ }^{86}$

Today, the right to education is fully complied with in most democracies. But some schools are more equal than others. This is particularly, though not exclusively, the case in the United States.

83. This concise phrase is borrowed from the casebook by KATHLEEN M. SULLIVAN \& GERALD GUNTHER, CONSTITUTIONAL LAW 680 (17th ed. 2010).

84. Dandridge v. Williams, 397 U.S. 471,485 (1970).

85. Lindsey v. Normet, 405 U.S. 56, 74 (1972).

86. MARSHALL, supra note 81 , at 25. 
Called upon to rule on the constitutionality of huge discrepancies between U.S. public schools in the light of the Fourteenth Amendment promise of "equal protection of the laws" for all U.S. children, the Court dodged the issue. ${ }^{87}$ In San Antonio Independent School District $v$. Rodriguez, ${ }^{88}$ which challenged the constitutionality of public schools being financed almost exclusively by means of property taxes, the Court departed from the Warren Court's approach to education, which it regarded as "the most important function of state and local governments[,] . . . the very foundation of good citizenship." 89 Without a single reference to citizenship, Justice Lewis F. Powell wrote and the Court held,

[T] he importance of a service performed by the State does not determine whether it must be regarded as fundamental.

It is not the province of this Court to create substantive constitutional rights in the name of guaranteeing equal protection of the laws. Thus, the key to discovering whether education is "fundamental" is not to be found in ... the ... societal significance of education .... Rather, the answer lies in assessing whether there is a right to education explicitly or implicitly guaranteed by the Constitution. ${ }^{90}$

But citizenship implies education, by definition. This is so true that education became compulsory in the nineteenth century precisely to enable citizens to fulfill their civic duties.

Another example of how the conservative creed of self-reliance has diminished the social rights of citizenship is the relaxation of due process requirements for withdrawing social entitlements. In 1970, in the wake of analysis on the "new property,"91 the Court ruled that social benefits were legal entitlements that could be not be withdrawn without due process of law, that is to say, without a judicial hearing, thus requiring a procedure extremely protective of the beneficiaries of the

87. U.S. CoNST. amend. XIV, $§ 1$.

88. San Antonio Indep. Sch. Dist. v. Rodriguez, 411 U.S. 1 (1973).

89. Brown v. Bd. of Educ., 347 U.S. 483, 493 (1954).

90. Rodriguez, 411 U.S. at $30,33$.

91. See Charles A. Reich, The New Property, 73 YALE L.J. 733 (1963). 
welfare state. Six years later, thanks to the new conservative justices, ${ }^{92}$ the Court reversed course. In Mathews v. Eldridge, it decided that due process depended on three distinct factors: (1) the private interest affected by the official action (some hardships are more difficult to endure than others); (2) the risk of an erroneous deprivation of such interest; and (3) the Government's interest, including the fiscal and administrative burdens that additional or substitute procedures would entail. ${ }^{93}$ In short, the Court made it easier for the State to withdraw its protection from those in need, implicitly forcing them to be self-reliant even in the defense of their own rights.

\section{The Reorientation of Affirmative Action}

In the 1960s, the idea that some affirmative action must be undertaken on the behalf of those who do not have equal opportunities to make a good start in life-ironically due in part to the inequalities between educational facilities at the primary and secondary levelsdeveloped among the white liberal elite. Announced in 1962 by President John F. Kennedy as a public policy henceforth to be pursued by the federal government, affirmative action figured as a top-priority target on the conservative agenda, probably because no other idea is more antithetical to self-reliance.

In the historic case Regents of the University of California v. Bakke, Justice Powell was the first to deal a severe blow to affirmative action by qualifying the notion of societal discrimination-discrimination caused by society, not by the state, "as an amorphous concept of injury that may be ageless in its reach into the past." 94 Justice Powell issued a strong warning against the use of such a malleable concept by political organs because it is "free from exacting judicial scrutiny." $95 \mathrm{He}$ explained his misgivings as follows: "There is no principled basis for deciding which groups would merit 'heightened judicial solicitude' and which would not."96 That was written in 1978, and Justice Powell was then alone in his attack against the "amorphous concept." Eight years

92. Nixon named four conservatives: Warren E. Burger as Chief Justice, Harry A. Blackmun, Lewis F. Powell, and William H. Rehnquist. For the first time in more than three decades, these appointments gave the Supreme Court a conservative majority. DAvid C. Whitney \& RoBerT VAughn Whitney, The AMERICAN PREsidents 367 (11th ed. 2009). True, Justice Blackmun eventually turned into a liberal as a result of a personal transformation analyzed in his biography. LINDA GREENHOUSE, BECOMING JUSTICE BLACKMUN (2005).

93. See Mathews v. Eldridge, 424 U.S. 319, 335 (1976).

94. Regents of the Univ. of Cal. v. Bakke, 438 U.S. 265, 307 (1978).

95. Id. at 297.

96. Id. at 296 (footnote omitted). 
later, in 1986, he was alone no longer. In Wygant v. Jackson Board of Education, Chief Justice Burger, Justice Rehnquist, and Justice O'Connor joined him in considering that "[s]ocietal discrimination, without more, is too amorphous a basis for imposing a racially classified remedy."97 In 1989, Justice O'Connor dealt the death-blow to the idea of societal discrimination in the case of City of Richmond v. J.A. Croson when she gathered a majority behind her, including Chief Justice Rehnquist, and Justices White, Stevens, and Kennedy, to affirm that "a generalized assertion that there has been past discrimination in an entire industry provides no guidance for a legislative body to determine the precise scope of the injury it seeks to remedy." 98 Justice Marshall was justified and very lucid to write in his dissent: "[T]oday's decision marks a deliberate and giant step backward in this Court's affirmativeaction jurisprudence."99 Indeed, as to affirmative action as a remedy against past discriminations, Croson, for all intents and purposes, limited its application to those situations in which "a prima facie case of a constitutional or statutory violation by anyone" 100 could be made. Affirmative action survives, but not as a remedy to help those who cannot be self-reliant. It survives as a means to ensure diversity, and in education only.

Even narrowed down to a mere device for ensuring diversity of the student body, affirmative action may greatly serve citizenship. In his essay Active Liberty, Justice Breyer made that point very clear when he referred to Justice O'Connor's defense of affirmative action in Grutter v. Bollinger: "[N]owhere is the importance of . . . openness more acute than in the context of higher education. Effective participation by members of all racial and ethnic groups in the civic life of our Nation is essential if the dream of one Nation, indivisible, is to be realized."101 Based on O'Connor's defense above, Breyer argues: "What are these arguments but an appeal to principles of solidarity, to principles of fraternity, to principles of active liberty."102 Judge Richard A. Posner has already noted that behind Breyer's enthusiastic support for affirmative action, there was a vibrant defense of republican citizenship. Affirmative action and republican citizenship go hand-in-hand, a combination that has led the conservative judge to object with obvious disapproval: "Solidarity and fraternity, yes, and these were ideals of Athenian society as of the French Revolution, but they are not, as [Justice Breyer] implies,

97. Wygant v. Jackson Bd. of Educ., 476 U.S. 267, 276 (1986).

98. City of Richmond v. J.A. Croson Co., 488 U.S. 469, 498 (1989).

99. Id. at 529 (Marshall, J., dissenting).

100. Id. at 500 (emphasis omitted).

101. Grutter v. Bollinger, 539 U.S. 306, 332 (2003) (citation omitted).

102. BREYER, supra note 69 , at 82 (emphasis omitted). 
democratic ideals."103 Many people would say that solidarity and fraternity are quintessential democratic ideals. Solidarity, which is subsumed under "fraternity," is among the ideals of the French Republic. ${ }^{104}$ It is also a constitutional value of the European Union. No fewer than twelve articles of the European Union's Charter of Fundamental Rights are provided for under that value in a section expressly titled "Solidarity."105

Are the values of fraternity and solidarity enthusiastically defended by Justice Breyer so much at odds with U.S. ideals, the only true "democratic" ideals, as Judge Posner insinuates? The answer depends on what is meant by citizenship, and the truth of the matter is that its meaning is no longer the same after the conservative movement. Citizenship is no longer associated with social equality. Conservatives were so much opposed to social rights regarded as necessarily implied by citizenship that they relentlessly worked at keeping them totally separated. They argued that social rights do not belong to the public domain, but rather to the private sphere; that social rights should never depend on public coercion (especially taxation and redistribution of wealth through the national budget), ${ }^{106}$ but rather, should depend on personal inclinations, such as Margaret Thatcher's "Victorian virtues" of, "thrift, self-discipline, responsibility, pride in and obligation to one's community," 107 or the qualities of "compassionate conservatism" extolled by President George W. Bush. ${ }^{108}$ They did so well that citizenship for a

103. Richard A. Posner, Justice Breyer Throws Down the Gauntlet, 115 YALE L.J. 1699, 1710 (2006).

104. See 1958 CONST. 1 \& 2 (Fr.), available at http://www.assembleenationale.fr/english/8ab.asp ("France shall be [a] . . social Republic . . . The maxim of the Republic shall be 'Liberty, Equality, Fraternity."). See also 1946 CoNST. pmbl. § 12, available at http://www.conseil-constitutionnel.fr/conseil-constitutionnel/root/bank_mm/ anglais/cst3.pdf.d

105. See Charter of Fundamental Rights of the European Union arts. 27-38, Dec. 18, 2000, 2000 O.J. (C 364) 15, available at http://www.europarl.europa.eu/charter/pdf/ text_en.pdf. In addition, the Charter contains six other chapters, five of which are respectively dedicated to "Dignity," "Freedoms," "Equality," "Citizens' Rights," and "Justice." See id. chs. 1, 2, 3, 5 \& 6 .

106. Hence the individual mandate introduced in the Patient Protection and Affordable Care Act, which requires most Americans to maintain "minimum essential" health insurance coverage. 26 U.S.C. $\$ 5000 A$ (2012).

107. Margaret Thatcher, The Path To Power 554 (1995).

108. Fact Sheet: Compassionate Conservatism, GEORGE W. BUSH WHITEHOUSE (Apr. 30, 2002), http://georgewbushwhitehouse.archives.gov/news/releases/2002/04/20020430.html (quoting President George W. Bush) ("I call my philosophy and approach compassionate conservatism. It is compassionate to actively help our fellow citizens in need. It is conservative to insist on responsibility and results. And with this hopeful approach, we will make a real difference in people's lives."). 
majority of the public means one thing only: the right to vote. Conservatives buried all other political rights.

\section{B. The Depreciation of Political Rights}

Political rights are citizens' rights par excellence. They stand for the right to participate in the public life of the state to its fullest extent, that is, to alternatively govern and be governed, in accordance with the exact definition of a citizen by Aristotle. ${ }^{109}$ For, undoubtedly, political rights include not only the right to vote, but also the right to be voted upon. Concretely, being a citizen does not mean only the right to choose the highest public officers; it also implies the right to be one of them, to run for those offices and to hold those positions in turn. To be a citizen in a democracy implies the right to actively participate in the government either by voicing personal opinions in the deliberative process, or by taking part directly in its activities as an officer. If Lincoln's definition of a republic, "a government of the people, by the people, for the people,"110 means something, it is that government in a republic is not external to the people. Political rights are the means by which that proximity takes shape.

Traditionally, political rights were held to be exercised within the public sphere or public domain, that is, a space "carve[d] out from the encircling market and private domains . . . [and] governed by nonmarket and non-private norms." 111 The state and the market were two different entities, clearly distinct and separate. The public domain was considered as subject to rules of public morality whose standards were higher than those that governed the market. Ideally, it was held to be special, different from day-to-day civil society. The values of the public domain and the market were regarded as different, opposite even, with altruism and disinterestedness ruling the former, and self-interest and profit seeking governing the latter. Citizenship was regarded as a public office proudly held by those admitted to exercise it. The franchise gave a

109. See ARISTOTLE, Politics bk. III, $\$ 1$ (Benjamin Jowett trans., n.d.) (c. 350 B.C.), available at $\mathrm{http} / / \mathrm{www}$.constitution.org/ari/polit_03.htm.

110. Lincoln's definition of the republican form of government was adopted word-for-word as "the principle" of the French republic in 1946. 1946 CONST. 2, translated in LIONEL H. Laing et AL., Source Book in European Governments 96, 98 (Info. Div. of the French Embassy trans., 1950), available at http:/heinonline.org.ezproxy.lib.indiana.edu/HOL/Page?handle=hein.cow/zzfr0148\&collectio $\mathrm{n}=$ cow. The same definition is repeated in the Constitution of October 4, 1958. 1958 ConsT. 2, translated at World Constitutions Ilustrated, HeINONLINE (Oct. 1, 2009), http:/heinonline.org.ezproxy.lib.indiana.edu/HOL/Page?handle=hein.cow/zzfr0001\&collectio $\mathrm{n}=\mathrm{cow}$ (Constitutional Council of France trans., 2009).

111. MARQUAND, supra note 48 , at 41. 
social status to its beneficiaries, ${ }^{112}$ so much so that it used to be that people dressed up to go to the polls. It would not have occurred to anyone that the public domain was a "market." Or, if it did, it was in a humorous vein, as when Mark Twain characterized the erratic behavior of a young man who happened to be "Whig to-day, Democrat the next week, and anything fresh that he could find in the political market the week after,"113 or as when Sir Arthur James Balfour, commenting upon the fate of a bill laid on the table of the House of Commons, predicted that "[t]he result will doubtless be determined by the 'higgling' of the "political market."'114

Today, the term "political market" is part of vernacular language as well as of scientific studies. The public domain is a market. It is routinely presented as entirely governed by the individual preferences of its actors, voters, and candidates. How can we explain such a transformation? The answer lies in one single fact: economic analysis rules the study of political behavior and process. An economic approach has displaced the institutional and legal approach that was based on procedural perspectives. This is not the place to recall how this development took place. Suffice it to say that it emerged out of the systemic analysis developed by David Easton in political theory. ${ }^{115}$ In the early 1950s, after Gabriel A. Almond identified the Anglo-American political systems as "saturated with the atmosphere of the market,"116

112. In France, under the so-called "Monarchy of July," when universal suffrage no longer existed (it had been withdrawn after the fall of Napoléon and the Restoration of the monarchy), the following dialogue took place between the President of the Court and the accused (Louis-Auguste Blanqui, a famous French revolutionary) at the beginning of the trial of the "Société des amis du peuple" in 1832:

The President to the accused: Your name?

-Louis-Auguste Blanqui

-Your age?

-26

-Your status?

-Proletarian

The President: That is not a status.

Blanqui: What do you mean, it's not a status! It's the status of 30 million of French people who live from their work and who are deprived of political rights!

The President: All right! Let it be then. Registrar, write that the accused is proletarian."

PIERRE ROSANVALLON, LE SACRE DU CITOYEN 338 (2001).

113. Mark Twain, Chapters from my Autobiography.-X., 184 N. AM. REV. 113, 115

(1907) (emphasis added).

114. Arthur James Balfour, The New House of Commons and the Irish Question, $155 \mathrm{~N}$. AM. REV. 641, 648 (1892) (emphasis added).

115. See David EASTON, The POlitical System: AN INQUIRY InTo THE State of Political SCIENCE 90 (1953).

116. Gabriel A. Almond, Comparative Political Systems, 18 J. PoL. 391, 398 (1956). 
meaning, free, open, and competitive. The term "political market" came to designate the public domain, whose role model was the market place of liberal economies. It did not take long before the image of the market turned into the criterion of liberal political systems.

The problem is that with the word "market" came the culture associated with it. The values of the marketplace became those of the public domain. As producers and consumers are driven by their own private interests in the marketplace, politicians and electors, too, are regarded as driven by individual preferences on the political market. That unfortunate result explains the impressive success of public choice theory that has accustomed the public to view legislation as "the result of a political market, with demand and supply features."117 The marketization of politics changed the nature of the public domain insofar as business morality replaced public morality. Politicians are expected to be driven by their individual preferences, and citizens legitimately exercise their political rights as buyers (of public goods) and sellers (of personal votes). "Uncivism" has been turned into a right. Under such circumstances, political rights either have been turned into a commodity that can be bought on the market like bushels of wheat (such is the case of the public offices that are filled by election), or they have been silenced because their object was transferred from the public to the private sector (such is the case with the right of the governed to hold officials accountable for their administration, which turns into an elusive promise when public services are privatized).

\section{The Right to Run for Office}

No political right has been more affected by the paradigm of the market than the right to run for office. As mentioned before, that right is the mirror of the right to vote in a republic. However, due to the conservative jurisprudence on the role of money in politics, that right seems nowadays to be located in a very distant mirror, to the point that it is inaccessible for a majority of the citizenry. Not only is the price to pay for advertisement to get a chance to be elected beyond the means of most citizens, but also, and more importantly, some citizens may drive their competitors out of the market just because of their wealth. There is hardly another political right that has been more deeply affected by the conservative movement than that to run for office. Money draws the

117. Daniel A. Farber, William N. Eskridge, JR. \& Philip P. Frickey, Cases and Materials on CONSTITUTIONAL LAW: Themes FOR THE CONSTITUTION'S THIRD CENTURY 155 (4th ed. 2009). 
line between those who may expect a public office and those who may not. Nobility by wealth has replaced nobility by birth.

Nobility by wealth is the legacy of Buckley $v$. Valeo, ${ }^{118}$ a landmark case of the Justice Burger Court that stands for the following proposition: "money is speech." 119 Of course, money is not speech; money is property, hence power, and power buys speech. Money therefore "enables speech," as Justice Breyer said. ${ }^{120}$ What is, however, interesting in that wrongful equation between money and speech is that it gave the Court the possibility to adjudicate the case under one, and only one, single provision-the First Amendment. Buckley reviewed the Federal Election Campaign Act under that provision only. The other provision that had a bearing on the case, the Equal Protection Clause (guaranteed to citizens by both the Fifth and Fourteenth amendments), was barely addressed by the Court, which regarded the argument made by the appellees aimed at grounding limitations on electoral expenditures on a possible "equaliz[ation] [of] the relative ability of individuals and groups to influence the outcome of elections" as "ancillary." ${ }^{21}$ Leaving aside the weak legal foundations of this dogmatic affirmation in the light of the proper methods of constitutional interpretation, ${ }^{122}$ the Court could not have said more clearly that substantive equality was a trifling matter in the electoral process.

118. Buckley v. Valeo, 424 U.S. 1 (1976).

119. Id. at 262 (White, J., concurring in part and dissenting in part).

120. United States v. United Foods, Inc., 533 U.S. 405, 425 (2001) (Breyer, J., dissenting) (quoting Nixon v. Shrink Mo. Gov't PAC, 528 U.S. 377, 398 (2000) (Breyer, J., concurring)).

121. Buckley, 424 U.S. at $48,54$.

122. Reliance on a single constitutional provision to review the constitutionality of a statute does not comport with the classical methods of constitutional interpretation. As Chief Justice John Marshall warned in a much celebrated statement, "we must never forget that it is a constitution we are expounding." McCulloch v. Maryland, 17 U.S. 316, 407 (1819). Arguably, that meant that the state of Maryland was wrong to rely on a single provision, a single word even-the adjective "necessary" in the "necessary and proper clause," U.S. CONST. art. I, § 8, cl. 18-to prove that the Bank of the United States was not necessary. The Constitution as a whole had to be taken into consideration, answered Marshall, because, as he put it, it does not "partake of the prolixity of a legal code . . . . [O]nly its great outlines [are] marked," with the result that, for "its receiving a fair and just interpretation," all its provisions are to be read together; all of them are connected to each other. Id. In that case, which raised the question of the necessity of a United States Bank, Marshall relied on both the taxation and the war powers to prove that, indeed, the bank was much needed, because, as he said, "Throughout this vast republic, from the St. Croix to the Gulf of Mexico, from the Atlantic to the Pacific, revenue is to be collected and expended, armies are to be marched and supported." Id. at 408. Must the Court not follow the same principle of interpretation when rights, not federal powers, are concerned? In Griswold v. Connecticut, 381 U.S. 479 (1965), the Court answered in the affirmative when it recognized a right to marital privacy as emanating from several provisions of the Bill of 
As long as formal equality is respected-as long as each citizen may expect to have his or her name on the ballot-constitutional equality is satisfied. The First Amendment trumps all other constitutional provisions, a hard fact that the Court summarized as follows: "[T] he concept that government may restrict the speech of some elements of our society in order to enhance the relative voice of others is wholly foreign to the First Amendment."123 The First Amendment therefore makes it impossible to limit the amount of money that circulates in the electoral process, save for one motive only, to prevent actual and apparent corruption. As to the poor candidate that has not accumulated "a huge campaign war chest," 124 it is too bad for her. Nothing in the Constitution protects her against being dwarfed and defeated by a millionaire-nothing, except federal and state citizenship recognized for "all persons born or naturalized in the United States." The conservative movement has divorced the most important right among political rights from citizenship. The only political right that has been left intact is the right to vote. But no matter how fundamental it is, the right to vote is not enough to make a republic, for it may also exist in a monarchy. What truly differentiates the citizen from the subject is that the latter is not necessarily entitled to occupy a public office, whereas the former is emphatically called to that station.

\section{The Right to Hold Officials Accountable}

To be a citizen gives the right to participate in the political process. That participation may take many forms. It may take place at the ballot box, in the media, and today, on the social networks. But the right of the citizen cannot be subsumed solely under a right to be publicly vocal. It materializes into the right to make determinations that will affect the rights and interests of those who compete to get power or to keep it. Of particular importance in that respect is the right to hold officials accountable to their mandate.

Accountability is usually verified at elections, when incumbents run for further service. The right of citizens to hold their congressional representatives accountable for the public policies supported while in office by voting them out is crucial to the integrity of the democratic

Rights read and taken together as a whole. Principled methods of constitutional interpretation cannot justify that different methods may apply to the Bill of Rights and to the Constitution. If so, what is it, then, that would justify reviewing campaign finance cases against freedom of speech only? Save for Buckley $v$. Valeo, which dodged the question, the Court has never given an answer.

123. Buckley, 424 U.S. at $48-49$.

124. Id. at 265 (White, J., concurring in part and dissenting in part). 
process. In U.S. Term Limits, Inc. v. Thornton, the Court held unconstitutional an attempt by Arkansas to limit that right by imposing fixed terms limits on congressional representatives and senators. ${ }^{125} \mathrm{But}$, with privatization of so many public services, that right dwindles, for the private sector takes the place of elected officials in deciding public policies. This is what has happened in domains such as education and public health, where citizens were accustomed to acting in pursuance of public choices. Privatization converted these public choices into private choices. With their privatization programs, conservatives obliged individuals, who are citizens and electors, to act according to their own private choices, like consumers in the market place.

Education is a case in point. After the Supreme Court refused in 1973 to invalidate the huge financial inequities between school districts as incompatible with equal protection, ${ }^{126}$ the matter was sent back to the state courts, which did not fare better in finding a solution to the problem. ${ }^{127}$ Eventually, it was decided that states should encourage market competition among private and public schools by subsidizing tuition costs for private school attendance. ${ }^{128}$ This is how school vouchers as a method for financing schools became more effective than public appropriations in carrying out educational public policies. Private choice replaced public choice, and reliance on private choices to carry out public policies grew in proportion. The end result is that, should the public service of education not educate children the way it ought to, citizens may no longer turn to their elected representatives and the political process to change the course of action. Decisions in the field of public education have been shifted to the market; citizens may no longer blame public officers, but themselves; they have been transformed into consumers. Privatization may not have a detrimental effect on citizenship when it is in the domain of, say, public transportation or public utilities, but when it comes to educational matters, indirect privatization of public schools is a problem for two reasons at leastfirst, because "the function of the school system is to give everyone the necessary abilities to effectively participate to public life and to occupy public positions," 129 and, second, because no public policy of education of substance may emerge from a multitude of private choices.

125. U.S. Term Limits, Inc. v. Thornton, 514 U.S. 779, 836 (1995).

126. San Antonio Indep. Sch. Dist. v. Rodriguez, 411 U.S. 1, 55 (1973).

127. See Sherry, supra note 14.

128. Id. at 199-200.

129. DOMINIQUE SCHNAPPER (with the collaboration of Christian Bachelier), QU'EST-CE QUE LA CITOYENNETÉ? 154 (2000). 


\section{CONCLUSION}

In conclusion, the legacy of the conservative movement with respect to citizenship is worrisome, to say the least. That notion which, throughout American history had already "proved to be an indeterminate legal concept," 130 has been torn into pieces. In exacerbating individualism and in encouraging huge financial inequalities between citizens through irresponsible tax policies based upon the idea that the wealth of the affluent class will trickle down throughout the channels of society and eventually reach the poor, ${ }^{131}$ the conservatives have eviscerated the meaning of citizenship. Weaving the social fabric back again between the people is the greatest challenge of globalization in the next twenty years.

Arguably, Chief Justice John Roberts made the first step in that direction when he justified the individual mandate requiring most Americans to buy health insurance by relying on the taxing power of Congress, not the commerce clause. ${ }^{132}$ For all intents and purposes, his legal reasoning means that citizens cannot opt out of citizenship at no cost-as the conservatives claimed-on the ground that Congress cannot regulate individuals "precisely because they are doing nothing."133 In supporting the constitutionality of the "shared responsibility payment" imposed on those who do not comply with the mandate by relying on political, not economic reasons, ${ }^{134}$ Chief Justice Roberts resurrected the true meaning of citizenship in a republic-

130. Stephen A. Conrad, Citizenship, in THE OXFORD COMPANION TO AMERICAN LAW 101, 101 (Kermit L. Hall et al. eds., 2002).

131. As Neil Brooks wrote in a prophetic piece,

[Taxes] have been reconceptualized in a way that makes them appear as illegitimate and inherently undesirable. They are frequently characterized as "impositions" over which taxpayers have no control, "burdens" from which they derive no benefit....

....

[The] tax-cutting agenda is profoundly wrong. In the long run it will increase social inequality, result in national economies being less productive, result in civil societies being less flourishing, and it will ultimately lead to social disintegration and a loss of a sense of connectedness between people.

Brooks, supra note 6, at 356-57.

132. See Nat'l Fed'n of Indep. Bus. v. Sebelius, 132 S. Ct. 2566, 2593, 2600 (2012).

133. Id. at 2587 (emphasis omitted).

134. Taxes are not merely what Louis Eisenstein called "a constitutional means of appropriating private property without just compensation," LOUIS EISENSTEIN, THE IDEOLOGIES OF TAXATION 6 (1961), available at http://heinonline.org/HOL/ Page?handle=hein.tera/idetaxn0001\&div=1\&g_sent=1\&collection=tera; they also "provide for the common Defence and general Welfare of the United States," U.S. CONST. art. I, § 8, cl. 1 . 
"interdependence on each other." 135 It is, however, too early to say whether that signal sent by the Chief Justice will be a shooting star in the night or the dawning of a new age.

135. Roosevelt, supra note 77 , at 14 . 